\title{
How reliable is anamnestic data in predicting the clinical relevance of house dust mite sensitization?
}

\author{
Anna S. Englhard ${ }^{1}$ (D) Martin Holzer ${ }^{1} \cdot$ Katharina Eder $^{1} \cdot$ Donata Gellrich $^{1} \cdot$ Moritz Gröger $^{1}$
}

Received: 9 December 2020 / Accepted: 30 April 2021 / Published online: 21 May 2021

(c) The Author(s) 2021

\begin{abstract}
Purpose For perennial inhalant allergens such as house dust mite (HDM), the German guideline on allergen-specific immunotherapy explicitly recommends provocation testing. This procedure is time-consuming, expensive, and potentially dangerous for the patient. Recently it has been discussed whether provocation tests are really necessary for diagnosing allergy to Dermatophagoides species. Thus, our study aimed to analyze the concordance between nasal provocation tests with Dermatophagoides species and anamnestic data.

Methods We retrospectively analyzed the concordance between patients' histories including self-reported symptom scores and the results of provocation testing in 471 individuals with proven sensitization to Dermatophagoides species.

Results 248 patients had a positive nasal provocation test (NPT) result to Dermatophagoides species and 223 individuals a negative NPT result. Patients allergic to HSM suffered significantly more often from atopic dermatitis ( $14 \%$ vs. $7 \%, p=0.046)$ and more from asthma $(20 \%$ vs. $19 \%, p=0.851)$. Moreover, individuals with clinically silent sensitization complained less about nasal secretion ( $37 \%$ vs. $45 \%, p=0.244)$ but significantly more about nasal dryness $(46 \%$ vs. $34 \%, p=0.046)$ whereas rates of nasal airway obstruction, ocular complaints and sleep quality were comparable in both groups. Allergic patients reported more often perennial (34\% vs. 30\%, $p=0.374$ ) and location-dependent (39\% vs. 31\%, $p=0.090$ ) symptoms. However, the discrepant prevalence of atopic dermatitis was the only statistically significant difference between both groups.

Conclusion Despite slight differences between both patient groups, clinical data are not sufficient to distinguish between silent sensitization and clinically relevant allergic rhinitis to HDM. Therefore, nasal provocation testing remains the gold standard for assessing clinical relevance in patients sensitized to Dermatophagoides species.
\end{abstract}

Keywords House dust mite $\cdot$ Sensitization $\cdot$ Allergy $\cdot$ Provocation test

\section{Introduction}

House dust mite (HDM) is the most important indoor allergen and one of the three most relevant aeroallergens responsible for the development of allergic symptoms such as allergic rhinitis or allergic asthma worldwide [1,2]. Data about the prevalence of allergy to HDM are inconsistent. The GA ${ }^{2}$ LEN study elicited relevant regional discrepancies

Anna S. Englhard and Martin Holzer contributed equally to this work.

Anna S. Englhard

Anna.Englhard@med.uni-muenchen.de

1 Department of Otorhinolaryngology-Head and Neck Surgery, Klinikum der Universität München, Marchioninistr. 15, 81377 Munich, Germany in the prevalence of sensitization to HDM in adults throughout Europe reaching rates from $9.3 \%$ in Sweden to $30.6 \%$ in Spain [3]. From a clinician's point of view, the incidence of allergic rhinitis (AR) upon exposure to HDM is obviously more relevant than clinically silent sensitization. This issue was addressed by the GA ${ }^{2} L E N$ skin test study II, published by Burbach et al. in which the authors differentiated between silent sensitization and clinically relevant sensitization assessed by experienced allergologists with the skin prick test (SPT), the history and further tests such as provocation testing in different European countries with different inhalant allergens. In case of HDM, they found that at least $80 \%$ of the participants with positive SPT reaction had a clinical relevant sensitization to HDM in most investigated countries. Only in France, Finland and Austria they revealed clinically relevant sensitization rates of less than $65 \%$ [4]. These findings were corroborated by a study of 
Blomme et al. in which the prevalence of silent sensitization and allergy to HDM in an unselected population in Belgium was analyzed by SPT and an interview of the participants about possible allergic symptoms. They found a prevalence of silent sensitization to HDM in $25.9 \%$ and symptoms of AR caused by HDM in $17.1 \%$ of the participants [5].

It has been demonstrated that untreated HDM allergy of the upper airway has the risk of transforming into a disease of the lower airways with full symptoms of allergic asthma [2, 6-8]. These results clearly underline the socio-economic impact of HDM allergy as a relevant disease generating high costs for the health care systems and severe complaints for lots of patients.

When diagnosing patients with allergic symptoms, a detailed medical history and thorough physical examination are the important first steps $[9,10]$. This procedure should be followed by SPT [10]. Patients suffering from one single seasonal allergy, for example to grass pollen, can be diagnosed by history and positive SPT alone in case they report about reproducible allergic symptoms occurring every year at the same specific time [11]. In contrast, perennial allergens like HDM frequently cause unspecific symptoms throughout the year in divergent intensity [12]. For this reason it can be difficult to match the patients' complaints and the exposition to the allergen only based on the history. As a consequence, further diagnostic steps such as determination of specific immunoglobulin E (sIgE) to Der p 1, Der p 2 alone or in combination with SPT might be necessary $[9,11]$. However, both, SPT and sIgE may only detect sensitization, which is not equivalent to a clinically relevant allergy as underlined above. Thus, the German guideline on allergen-specific immunotherapy [13] in IgE-mediated allergic diseases explicitly recommends provocation testing for perennial inhalant allergens such as HDM before initiating allergen immunotherapy [13, 14]. In case of AR, this approach usually takes the form of specific nasal provocation testing (NPT) [15]. As NPT is a relatively complex procedure and most clinicians even do not have the technical option to perform it, an easier way to differentiate between clinically relevant and irrelevant HDM sensitizations is desirable. Although there are several studies analyzing the correlation between NPT and SIgE-serology in HDM sensitization $[16,17]$, there is to our knowledge no data in literature on the concordance between anamnestic data and NPT in HDM sensitized patients. Therefore, there is a need of an evidence-based study to confirm the general assumption that medical history is too inconsistent in HDM patients making allergen challenge testing necessary.

Thus, the purpose of our study was to compare the medical history of patients with clinically silent sensitization and those with clinically relevant allergy to HDM. We aimed to identify specific questions, which could facilitate a differentiation of both patient groups based on medical history. This could help to avoid time-consuming and risky procedures like NPT at least in some patients.

\section{Materials and methods}

\section{Study population}

Patients presenting at our institution, the Department of Otorhinolaryngology of the Ludwig-Maximilians-University, Munich, Germany, received the SX1-screening test [18], if an allergic cause of their complaints was reasonable. The SX1 is an in vitro screening test for inhalant allergy (Phadiatop, Pharmacia Uppsala, Sweden). The test is based on the Fluoroenzyme immunoassay-Test (CAP-FEIA). Specific IgE antibodies to different inhalant allergens like, HSM, birch, grass, rye, cat, dog, mugwort and cladosporium are detected simultaneously. Our group was able to demonstrate the value of this test for screening some time ago [19]. In case of a positive screening test result or in case of a negative test result but persisting clinical suspicion (location-dependent symptoms, symptoms in beds, allergic asthma), the patient was recommended to attend the allergologic consultation hours for further clarification. Within this appointment, each patient had to fulfill a detailed questionnaire, comprising standardized questions of the most relevant symptoms over the last 7 days adopted from the Rhinoconjunctivitis Quality of Life Questionnaire (RQLQ) [20, 21] in German language. The adapted questionnaire we used for the presented study contains of two parts: the first part consists of a general allergologic history, e.g. questions about location dependency, allergic family members, seasonal symptoms, home environment including indoor pants, carpets, age of mattress, use of encasings, history of allergic shock, history of asthma, and history of food intolerance. The second part comprises standardized questions of the most relevant symptoms over the last 7 days. Patients were asked to rate their symptoms on a scale from 0 to $3(0=$ no complaints, $1=$ slight complaints, $2=$ mild complaints, $3=$ severe complaints). The questionnaire includes nasal symptoms, reduced physical performance, sore throat, headache, sleep dependent symptoms, ocular complaints, asthmatic symptoms, complaints related to food intolerance, dermatologic symptoms, and emotional complaints.

In addition to this questionnaire, the attending physician took the history followed by SPT, blood test and in case of suspected HDM allergy by NPT. The questionnaire and the patient's history were saved together with the results of the examinations as a complete data set for each patient. Consequently, this procedure generated a preselected but suitable database containing many data sets of mono- or polysensitized but also of mono- and polyallergic patients. For the purpose of the presented study, this allergy database 
was scanned retrospectively to identify patients with proven sensitization to HDM based on a positive SPT result and/ or a positive sIgE measurement. All subjects included had underwent SPT and allergen-specific provocation as routine in vivo tests and total $\mathrm{IgE}$ and allergen-specific IgE measurements in serum as in vitro tests. The study was based on anonymized data and approved by the local ethics committee. All patients provided their written informed consent for the use of their data for scientific purposes.

\section{Skin prick testing}

SPT was performed with a solution for HDM testing (ALKAbelló, Copenhagen, Denmark) according to published guidelines [22]. We performed SPT to birch, hazel, alder, ash, tomithy grass, rye mugwort, pellitory, ragweed, Dermatophagoides pteronyssinus, Dermatophagoides farina, dog, cat, Alternaria and Aspergillus.

\section{Fluorescence enzyme immunoassay}

IgE reactivity to natural allergen extract (d1) and allergen components Der $\mathrm{p} 1$ and Der $\mathrm{p} 2$ was measured using fluorescence enzyme immunoassay (UniCAP-FEIA, ThermoFisher Scientific, Freiburg, Germany) with a commercially available test kit (Phadia Diagnostics, Uppsala, Sweden). In case of a positive SPT result to allergens other than HDM, specific IgE antibodies to the corresponding native extracts and allergen components were also measured. Results were reported as concentrations (kU/L). The positive cutoff value was $>0.35 \mathrm{kU} / \mathrm{L}$ as suggested by the manufacturer.

\section{Nasal provocation testing}

In accordance with current guidelines, all patients sensitized to HDM underwent NPT [14]. The protocol used in this study has been previously described [23]. Following the German position paper regarding NPT, following carence times were respected: DNCG, Nedocromil 3 days, nasal corticosteroids 7 days, oral corticosteroids 7 days, nasal antihistamines 3 days, oral antihistamines 3 days, nasal alpha-adrenergics 1 day, tricyclic psychotropic drugs 3 days [24, 25]. Following exclusion criteria were applied: acute infectious diseases of the nose or the paranasal sinuses, acute allergic reactions in other parts of the body, severe general illness, nasal operations less than 2 months ago, treatment with beta-blockers, and vaccination 1 week before the NPT. Relative contraindications were pregnancy, age below 5 years and extremely high grade of sensitization. Patients with only partly controlled or uncontrolled asthma (following the GINA guidelines [26] including FEV1 $<80 \%$, symptoms more often than twice a week during the day, nocturnal symptoms, emergency medication necessary more often than twice a week) were transferred to the department of pulmonary medicine prior to NPT. We performed nasal endoscopy in all patients before they underwent NPT. Prior to NPT patients had $30 \mathrm{~min}$ time to adapt to the climatic circumstances of the examination room. Patients received two puffs of challenge solution. After each application individuals waited for $10 \mathrm{~min}$ before rhinomanometry was performed and their symptoms were evaluated. Patients were diagnosed to have an unspecific challenge reaction in case that after the administration of allergen-free solution a flow reaction of more than $20 \%$ was seen. First, active anterior rhinomanometry (RhinoSys, Happersberger otopront $\mathrm{GmbH}$, Hohenstein, Germany) was performed to obtain a baseline measurement. It was repeated after the administration of allergen-free solution (LETI Pharma $\mathrm{GmbH}$, Ismaning, Germany) and finally after the application of solution containing the allergen (D. pteronyssinus or farinae, $100 \mathrm{HEP} /$ $\mathrm{mL}$; LETI Pharma GmbH, Ismaning, Germany) via a nasal spray pump. As monosensitization to $D$. farinae is rare; in general, we performed NPT with D. pteronyssinus, only for monosensitized patients we used D. farinae. Moreover, patients reported their symptoms regarding secretion, irritation, and remote symptoms after each measurement and a symptom score was calculated (secretion: no secretion: 0 points, a little secretion: 1 point, a lot of secretion: 2 points, irritation: 0-2 times sneezing: 0 points, $3-5$ times sneezing: 1 point, $>5$ times sneezing: 2 points, and remote symptoms: no remote symptoms: 0 points, lacrimation and/or itching of the palate and/or itching of the ears: 1 point, conjunctivitis and/or chemosis and/or urticaria and/or cough and/or dyspnea: 2 points) [27]. NPT was considered positive for patients who showed either a decrease in airflow of $>40 \%$ at $150 \mathrm{~Pa}$ on the allergen-challenged side or a symptom score of $>3$, or a combination of a symptom score of $>2$ and a reduction in airflow of $>20 \%$. Secretion, irritation, and remote symptoms were semiquantitatively assessed to determine the symptom score. In patients with negative NPT results despite strong evidence in the history in favor of a clinically relevant HDM allergy, NPT was repeated with a different provocation test solution (Allergopharma GmbH, Reinbek, Germany). We controlled patients $30 \mathrm{~min}$ after NPT for security reasons. We did not observe any severe allergic reactions to NPT. As allergic late phase reactions of the nose have been described, we recommended our patients a self-observation of their symptoms during $24 \mathrm{~h}$.

\section{Statistical analysis}

The statistical analysis was performed with SPSS 23.0 (SPSS Inc., Chicago, Illinois). For descriptive statistics, median values and the standard deviation were used. For comparisons between different groups, Fisher's exact test 
was applied. Differences were considered statistically significant at $p<0.05$.

\section{Results}

Based on the above-mentioned inclusion criteria, the database search yielded 471 patients with proven sensitization to $D$. pteronyssinus or D. farinae. $90 \%$ of patients were sensitized to $D$. pteronyssinus and $93 \%$ were sensitized to $D$. farinae. $85 \%$ were sensitized to both, $D$. pertonyssinus and $D$. farinae. Only $6 \%$ of the individuals were monosenitized to $D$. farinae. The study population was divided into two groups: 248 patients with a positive NPT result to $D$. pteronyssinus or farinae and 223 with a negative NPT result.

Important for statistical analysis, the distribution of mono- (sensitization to one allergen only) and polysensitization (sensitization to more than one allergen) was comparable in both groups. Detailed demographic data of our study population are summarized in Table 1.

We found a trend that patients allergic to HDM complain more often about perennial symptoms than subjects with clinically silent sensitization ( $34 \%$ vs. $30 \%, p=0.374$ ).

Concerning nasal symptoms, as reported by patients in the questionnaire recording medical history, rates of nasal airway obstruction were comparable in both groups $(66 \%$ vs. $69 \%, p=0.630)$. Patients allergic to HDM tend to suffer more often from nasal secretion $(45 \%$ vs. $37 \%, p=0.244)$ but significantly less from nasal dryness ( $34 \%$ vs. $46 \%$, $p=0.046$ ).

With regard to ocular complaints, significantly more patients only sensitized to HDM reported about red eyes than patients with positive NPT to HDM (13\% vs. 4\%, $p=0.008$ ). Moreover, within the group of polysensitized participants, significantly more patients with negative NPT to HDM suffered from red eyes ( $14 \%$ vs. $4 \%, p=0.017$ ).
The rate of ocular itching was comparable in both groups (39\% vs. $40 \%, p=0.834$ ). However we observed the trend that patients in the monosensitized subgroup with positive NPT reported more often about this condition (28\% vs. $20 \%, p=0.357)$.

Concerning atopic co-morbidities, the prevalence of self-reported asthma was comparable in both groups ( $20 \%$ vs. $19 \%, p=0.851$ ). However, in the subgroup of monosensitized patients, individuals allergic to HDM complained more frequently about asthma (0\% vs. $5 \%$, $p=0.061$ ), whereas there was no single asthmatic person among patients with a clinically silent monosensitization to HDM. Patients in the positive NPT group suffered significantly more often from atopic dermatitis ( $14 \%$ vs. $7 \%$, $p=0.046$ ).

With regard to sleep quality, patients with clinically silent sensitization to HDM tended to be more often affected by un-restorative sleep ( $44 \%$ vs. $38 \%, p=0.293$ ). Symptoms in the morning were comparable between both patient groups: only slightly more patients allergic to HSM complained about symptoms in the morning ( $51 \%$ vs. $49 \%$, $p=0.724)$. Markedly, but not significantly more patients with silent sensitization reported about snoring (33\% vs. $23 \%, p=0.072$ ). However, the number of patients reporting about a dry mouth at night or in the morning was equal ( $44 \%$ vs. $40 \%, p=0.563$ ). All clinical data of the study population obtained are summarized in Table 2.

In Table 3, additional information about the patients' home environment is listed. Patients allergic to HDM seem to have suffered more often from location-dependent symptoms than subjects with clinically silent sensitization (39\% vs. $31 \%, p=0.090$ ). While the age of the mattresses used by the patients of both main groups was comparable ( $39 \%$ vs. $37 \%, p=0.723$ ), patients allergic to HDM used encasings for their mattresses and pillows (23\% vs. $18 \%$, $p=0.127$ ) more frequently. In Table 4 , laboratory characteristics are listed.

Table 1 Demographic data of patients allergic to HDM and patients with clinically silent sensitization

\begin{tabular}{|c|c|c|c|c|}
\hline Characteristics & Negative NPT $(n=223)$ & Positive NPT $(n=248)$ & Total $(n=471)$ & Significance \\
\hline Gender & & & & 0.701 \\
\hline Male & $131(59 \%)$ & $150(61 \%)$ & $281(60 \%)$ & \\
\hline Female & $92(41 \%)$ & $98(40 \%)$ & $190(40 \%)$ & \\
\hline Age & $34(16 ; 6-74)$ & $29(14 ; 5-81)$ & $32(17 ; 5-81)$ & 0.610 \\
\hline Sensitization & & & & 0.717 \\
\hline Monosensitized to HDM & $57(27 \%)$ & $61(26 \%)$ & $118(26 \%)$ & \\
\hline Polysensitized & $153(73 \%)$ & $177(74 \%)$ & $330(74 \%)$ & \\
\hline Time of presentation & & & & 0.326 \\
\hline Winter (October-March) & $105(47 \%)$ & $128(52 \%)$ & $233(50 \%)$ & \\
\hline Summer (April-September) & $118(53 \%)$ & $120(48 \%)$ & $238(50 \%)$ & \\
\hline
\end{tabular}

Age is given as median (standard deviation, minimum and maximum) 
Table 2 Clinical data of patients allergic to HDM and patients with clinically silent sensitization (data taken from questionnaire recording medical history)
Table 3 Additional information about patients' home environment

\begin{tabular}{lcccc}
\hline Characteristics & $\begin{array}{l}\text { Negative NPT } \\
(n=223)\end{array}$ & $\begin{array}{l}\text { Positive NPT } \\
(n=248)\end{array}$ & Total $(n=471)$ & Significance \\
\hline Perennial complaints & $66(30 \%)$ & $83(34 \%)$ & $146(32 \%)$ & 0.374 \\
Location-dependent symptoms & $60(31 \%)$ & $76(39 \%)$ & $136(35 \%)$ & 0.090 \\
Nasal complaints & & & & \\
Nasal airway obstruction & $102(69 \%)$ & $108(66 \%)$ & $210(68 \%)$ & 0.630 \\
Nasal secretion & $53(37 \%)$ & $73(45 \%)$ & $126(41 \%)$ & 0.244 \\
Nasal dryness & $67(46 \%)$ & $54(34 \%)$ & $121(40 \%)$ & 0.046 \\
Ocular complaints & & & & \\
Red eye & $17(13 \%)$ & $6(4 \%)$ & $23(8 \%)$ & 0.008 \\
Monosensitized to HDM & $2(8 \%)$ & $1(3 \%)$ & $3(5 \%)$ & 0.556 \\
Polysensitized & $15(14 \%)$ & $5(4 \%)$ & $20(9 \%)$ & 0.017 \\
Itching & $73(40 \%)$ & $78(39 \%)$ & $151(39 \%)$ & 0.834 \\
Monosensitized to HDM & $10(20 \%)$ & $14(28 \%)$ & $24(23 \%)$ & 0.357 \\
Polysensitized & $63(48 \%)$ & $64(42 \%)$ & $127(45 \%)$ & 0.339 \\
Atopic dermatitis & $8(7 \%)$ & $20(14 \%)$ & $28(11 \%)$ & 0.046 \\
Asthma & $14(19 \%)$ & $22(20 \%)$ & $36(19 \%)$ & 0.851 \\
Monosensitized to HDM & $0(0 \%)$ & $5(17 \%)$ & $5(9 \%)$ & 0.061 \\
Polysensitized & $14(26 \%)$ & $17(21 \%)$ & $31(23 \%)$ & 0.541 \\
Sleep quality & $62(44 \%)$ & $61(38 \%)$ & $123(41 \%)$ & 0.293 \\
Un-restorative sleep & $58(40 \%)$ & $70(44 \%)$ & $128(42 \%)$ & 0.563 \\
Dry mouth at night & $46(33 \%)$ & $38(23 \%)$ & $84(28 \%)$ & 0.072 \\
Snoring & & &
\end{tabular}

\begin{tabular}{lllll}
\hline Characteristics & $\begin{array}{l}\text { Negative NPT } \\
(n=223)\end{array}$ & $\begin{array}{l}\text { Positive NPT } \\
(n=248)\end{array}$ & Total $(n=471)$ & Significance \\
\hline Location-dependent symptoms & $60(31 \%)$ & $76(39 \%)$ & $136(35 \%)$ & 0.090 \\
New mattress ( $\leq 2$ years) & $54(37 \%)$ & $61(39 \%)$ & $115(38 \%)$ & 0.723 \\
Encasings & $36(18 \%)$ & $53(23 \%)$ & $89(21 \%)$ & 0.127 \\
\hline
\end{tabular}

Table 4 Laboratory characteristics

\begin{tabular}{lclc}
\hline Laboratory characteristics & Positive NPT $(n=223)$ & Negative NPT $(n=248)$ & Total $(n=471)$ \\
\hline Total IgE $(\mathrm{kU} / \mathrm{L})$ & $320.98(573.89)$ & $284.66(423.42)$ & $303.72(507.78)$ \\
$\begin{array}{l}\text { D. pter } \\
\text { CAP class }\end{array}$ & $2.80(1.40)$ & $1.84(1.34)$ & $2.33(1.45)$ \\
Serum IgE (kU/L) & $16.56(24.94)$ & $6.91(17.11)$ & $12.06(22.15)$ \\
D. far & & & \\
CAP class & $2.70(1.57)$ & $1.63(1.45)$ & $2.17(1.60)$ \\
Serum IgE (kU/L) & $18.89(29.21)$ & $6.60(16.20)$ & $13.13(24.79)$ \\
\hline
\end{tabular}

Data are given as mean (standard deviation)

\section{Discussion}

Taking a detailed patients' history is a crucial part of the process of finding the correct diagnosis in allergic diseases [10]. In case of allergy to HDM, experts in the field of allergy and immunology recommend additional NPT besides the common practice of taking medical history and evaluating the SPT and/or specific IgE level before starting allergy immunotherapy $[13,28]$. A significant reason for this recommendation is that contrary to other aeroallergens such as pollen or pets, the symptoms patients allergic to HDM report of are considered as inconsistent. However, NPT has several disadvantages like time costs and induction of potentially harmful allergic reactions. In 
contrast to many evidence-based approaches in the field of allergy and immunology, to our knowledge, it has not been evaluated so far if it is possible to diagnose allergy against HDM based on the history only. Thus, the aim of this study was to evaluate retrospectively if the application of a standardized questionnaire alone-addressing the most relevant symptoms of AR-would be able to identify individuals with clinical relevant allergy to HDM.

Sensitization can be differentiated into monosensitization (sensitization against a single allergen) and polysensitization (sensitization against at least two allergens) [8]. In our study, sensitization was indicated either by a positive reaction on standardized SPT or positive serum sIgE-levels or both. According to epidemiological studies, polysensitization is more common than monosensitization $[29,30]$. This was also the case in our preselected cohort, since only $26 \%$ of all participants were monosensitized to HSM.

Encasings were prescribed for patients with positive a NPT result. Other typical measures against HSM (including removal of carpets and indoor plants) were recommended. In case they had no contraindications, patients were treated with a nasal cortisol spray. All patients were asked to make another appointment in our department after three months to reevaluate their complaints. In case no sufficient improvement with above-mentioned therapy measures was seen and patients had no contraindications, allergen immunotherapy was recommended.

Perennial rhinitis, which is a typical characteristic of HDM allergy, is most often defined by the persistence of at least two of the following symptoms over nine months: serous or seromucous hypersecretion, nasal blockage caused by a swollen nasal mucosa, or sneezing paroxysms. Nasal congestion and mucous production (postnasal drip) are also predominant in most patients, while sneezing, itching, and watery rhinorrhea may be minimal [31, 32].

Although nasal obstruction is one of the main symptoms affecting the quality of life of adolescents [33] and adults [34] suffering from perennial AR, we found no relevant difference in the degree of nasal obstruction reported by the participants of both groups. Nasal secretion, however, was a little bit more pronounced in our patients with positive NPT ( $45 \%$ vs. $37 \%$ ). Accordingly, nasal dryness was reduced within this group (34\% vs. 46\%). Nasal operations might influence nasal symptoms, especially nasal obstruction. In the presented study, we excluded patients with a history of nasal surgery less than 2 months prior to their presentation at our department. However, even earlier operations might have an impact on nasal symptoms. This might be a disadvantage of the study. Nevertheless, we assume that the influence of these operations on our data may be neglected, as we as we included a relatively large number of patients in both subgroups.

Our participants were also asked about their ocular complaints, comprising symptoms of bilateral red eyes but also itching and tearing of their eyes in general. Didier et al. reported in their cross-sectional observational survey about AR-associated ocular symptoms in $19 \%$ of the overall study population and $52 \%$ in the AR population of adults. Interestingly, HDM sensitization was one of the most important trigger factors of ocular symptoms (35\%) identified in this study [35]. Another cross-sectional study demonstrated that a physician diagnosis of conjunctivitis was in $16 \%$ of 1549 asthmatic children (mean age 4.3 years). $44 \%$ of these children had at least one ocular symptom (itching, lacrimation or redness) suggesting ocular allergy. Again, HDM were with $71.4 \%$ one of the most common sensitizing agents [36]. Interestingly, in our study significantly more patients with silent sensitization against HDM reported about symptoms of conjunctivitis than individuals with clinically relevant allergy ( $13 \%$ vs. $4 \%)$. This effect was especially pronounced in the polysensitized group (14\% vs. $4 \%$ ). A possible explanation for this finding might be, that polysensitized patients suffered from red eyes because of other allergens. However, the rate of ocular itching was comparable in both groups (39\% vs. $40 \%)$.

In summary, our questionnaire revealed no suitable differences in nasal or ocular symptoms between subjects with relevant allergy against HDM and individuals with silent sensitization, even though these findings are known to belong to the key symptoms of AR. Concerning the temporal and regional occurrence of allergic symptoms, we did not observe significant differences (see Table 2).

We also detected no difference in the prevalence of selfreported asthma between the two groups (20\% vs. $19 \%$ ). Overall, this is a much higher prevalence compared to the prevalence of asthma in Germany, reported to be 6.2\% [37], which is in line with the fact that asthma is more frequently seen in patients with allergen sensitization. In the monosensitized subgroup, there was no patient with asthma in the silent sensitization group, but five patients with asthma and allergy to HSM ( $0 \%$ vs. $17 \%$ ). This finding shows that there is a connection between allergy to HDM and asthma.

Besides causing allergic rhinitis and asthma, dust mite allergens are known to induce further atopic diseases such as atopic dermatitis (AD) [38]. AD is characterized by pruritus and chronic or relapsing eczematous lesions with typical morphology and distribution [39]. Several studies demonstrated a relationship between the exposure to high levels of HDM allergens in babyhood and the development of asthma [7, 40] and atopy [41] in childhood. Accordingly, Zureik et al. found in a huge cross-sectional study a positive association between sensitization to HDM and the severity of asthma [42]. Besides inhalation, a possible route of exposure to HDM allergens is direct contact with the skin [43, 44]. Consequently, it is not surprising that significantly more patients of our cohort, allergic to HDM, suffered from these atopic diseases in contrast to the control group of sensitized 
only patients ( $14 \%$ vs. $7 \%)$, underlining some representative character of our study population. The differences between the two groups were statistically significant but these items of our questionnaire alone are not useful for the differentiation between clinical relevant HDM allergy and pure sensitization.

A further part of the questionnaire deals with the possible impact of AR on different facets of sleep, comprising interruption of the sleep, un-restorative sleep, snoring, and dry mouth at night or in the morning. It is known that AR negatively affects sleep in many ways. This was confirmed by a meta-analysis of observational studies [45]. Nasal congestion, which is a typical symptom of AR, is a known risk factor for sleep-disordered breathing and snoring [46-48]. Thus, application of nasal corticosteroids positively affects sleep quality in patients with AR $[49,50]$. In contrast, in the presented study, there were no significant differences in the severity of symptoms related to sleep between the patients with HDM allergy and those with sensitization. Regarding some aspects (un-restorative sleep and snoring) individuals with silent sensitization tended to suffer slightly more often from reduced sleep quality. Other diseases also might influence sleep quality. These were not excluded in this study, which might influence the presented data. However, as we included a relatively large number of patients in both subgroups, we assume that this effect can be neglected.

The last part of our questionnaires addresses the home environment of the participants. This is especially important in case of HDM allergy because the bed and the mattresses are essential habitats for mites [2, 51]. Factors shown to decrease HDM concentrations in the home include use of newer mattresses and mite-impermeable mattress covers [52, 53]. Interestingly, more patients allergic to HDM reported about location-dependent complaints (39\% vs. $31 \%)$ and more often used encasings for their beds (23\% vs. $18 \%$ ). In contrast, the age of the mattresses possessed by both groups was comparable. One could speculate that the individuals affected by HDM allergy have already investigated their symptoms and tried to start action against them thereby emphasizing the pre-selection of the cohort presenting at a center of maximum care as our university hospital.

There are several discrepancies between the findings presented in this study and the cited results found in the literature. Some of this could be explained by different inclusion criteria and initial questions. Moreover, our study has a pre-selection bias, as all patients presented at a specialized university clinic due to upper airway complaints. Thereby this cohort is not representing the general population. However, patients presenting to a specialist in allergy and clinical immunology would have similar characteristics, underlining the importance of the questions we address. Besides this main limitation, slight additional drawbacks of our study have to be addressed. First, our questionnaire was adapted from the RQLQ $[20,21]$. It is a standardized but not a validated tool. Furthermore, some items are related to the last 7 days, which may lead to false negative results, for example if patients do not present in the main allergy season. Moreover, the questionnaire addressed subjective symptoms. Objective data, for example pulmonary function tests, was not collected. Last, all data were evaluated retrospectively. In spite of these limitations, the presented study shows important data on the concordance between anamnestic data and NPT in HDM sensitized patients. It confirms the current opinion that clinical data in HDM sensitized patients is insufficient for initiating allergen-specific immunotherapy.

\section{Conclusion}

Taken together, the results of our study corroborate the common concept in the field of allergy and immunology that taking patient's history alone seems not to be a suitable instrument for finding the correct diagnosis of allergy to HDM. As a consequence, further steps like nasal allergen challenge recommended by experts and known from the guidelines are still reasonable and inevitable.

Funding Open Access funding enabled and organized by Projekt DEAL.

\section{Declarations}

Conflict of interest M. G. has received speaker honoraria and financial support for attending symposia from ALK-Abelló, Allergopharma, Bencard Allergy, Glaxo Smith Kline, HAL Allergy, LETI Pharma, Novartis Pharma, Phadia diagnostics, Sanofi-Aventis, Shire and Stallergenes. A. E., M. H., K. E., and D. G. declare that they have no conflict of interest.

Open Access This article is licensed under a Creative Commons Attribution 4.0 International License, which permits use, sharing, adaptation, distribution and reproduction in any medium or format, as long as you give appropriate credit to the original author(s) and the source, provide a link to the Creative Commons licence, and indicate if changes were made. The images or other third party material in this article are included in the article's Creative Commons licence, unless indicated otherwise in a credit line to the material. If material is not included in the article's Creative Commons licence and your intended use is not permitted by statutory regulation or exceeds the permitted use, you will need to obtain permission directly from the copyright holder. To view a copy of this licence, visit http://creativecommons.org/licenses/by/4.0/.

\section{References}

1. Bousquet PJ, Chinn S, Janson C, Kogevinas M, Burney P, Jarvis D, European Community Respiratory Health Survey I (2007) Geographical variation in the prevalence of positive skin tests to environmental aeroallergens in the European Community 
Respiratory Health Survey I. Allergy 62(3):301-309. https://doi. org/10.1111/j.1398-9995.2006.01293.x

2. Calderon MA, Linneberg A, Kleine-Tebbe J, De Blay F, Fernandez H, de Rojas D, Virchow JC, Demoly P (2015) Respiratory allergy caused by house dust mites: what do we really know? J Allergy Clin Immunol 136(1):38-48. https://doi.org/10.1016/j. jaci.2014.10.012

3. Newson RB, van Ree R, Forsberg B, Janson C, Lotvall J, Dahlen SE, Toskala EM, Baelum J, Brozek GM, Kasper L, Kowalski ML, Howarth PH, Fokkens WJ, Bachert C, Keil T, Kramer U, Bislimovska J, Gjomarkaj M, Loureiro C, Burney PG, Jarvis D (2014) Geographical variation in the prevalence of sensitization to common aeroallergens in adults: the GA(2) LEN survey. Allergy 69(5):643-651. https://doi.org/10.1111/all.12397

4. Burbach GJ, Heinzerling LM, Edenharter G, Bachert C, BindslevJensen C, Bonini S, Bousquet J, Bousquet-Rouanet L, Bousquet PJ, Bresciani M, Bruno A, Canonica GW, Darsow U, Demoly P, Durham S, Fokkens WJ, Giavi S, Gjomarkaj M, Gramiccioni C, Haahtela T, Kowalski ML, Magyar P, Murakozi G, Orosz M, Papadopoulos NG, Rohnelt C, Stingl G, Todo-Bom A, von Mutius E, Wiesner A, Wohrl S, Zuberbier T (2009) GA(2)LEN skin test study II: clinical relevance of inhalant allergen sensitizations in Europe. Allergy 64(10):1507-1515. https://doi.org/10.1111/j. 1398-9995.2009.02089.x

5. Blomme K, Tomassen P, Lapeere H, Huvenne W, Bonny M, Acke F, Bachert C, Gevaert P (2013) Prevalence of allergic sensitization versus allergic rhinitis symptoms in an unselected population. Int Arch Allergy Immunol 160(2):200-207. https://doi.org/10.1159/ 000339853

6. Linneberg A, Henrik NN, Frolund L, Madsen F, Dirksen A, Jorgensen T, Copenhagen AS (2002) The link between allergic rhinitis and allergic asthma: a prospective population-based study. The Copenhagen Allergy Study. Allergy 57(11):1048-1052. https:// doi.org/10.1034/j.1398-9995.2002.23664.x

7. Sporik R, Holgate ST, Platts-Mills TA, Cogswell JJ (1990) Exposure to house-dust mite allergen (Der p I) and the development of asthma in childhood. A prospective study. N Engl J Med 323(8):502-507. https://doi.org/10.1056/NEJM199008233230802

8. Wise SK, Lin SY, Toskala E, Orlandi RR, Akdis CA, Alt JA, Azar A, Baroody FM, Bachert C, Canonica GW, Chacko T, Cingi C, Ciprandi G, Corey J, Cox LS, Creticos PS, Custovic A, Damask C, DeConde A, DelGaudio JM, Ebert CS, Eloy JA, Flanagan CE, Fokkens WJ, Franzese C, Gosepath J, Halderman A, Hamilton RG, Hoffman HJ, Hohlfeld JM, Houser SM, Hwang PH, Incorvaia C, Jarvis D, Khalid AN, Kilpelainen M, Kingdom TT, Krouse H, Larenas-Linnemann D, Laury AM, Lee SE, Levy JM, Luong AU, Marple BF, McCoul ED, McMains KC, Melen E, Mims JW, Moscato G, Mullol J, Nelson HS, Patadia M, Pawankar R, Pfaar O, Platt MP, Reisacher W, Rondon C, Rudmik L, Ryan M, Sastre J, Schlosser RJ, Settipane RA, Sharma HP, Sheikh A, Smith TL, Tantilipikorn P, Tversky JR, Veling MC, Wang Y, Westman M, Wickman M, Zacharek M (2018) International consensus statement on allergy and rhinology: allergic rhinitis. Int Forum Allergy Rhinol 8(2):108-352. https://doi.org/10.1002/alr.22073

9. Wise SK, Lin SY, Toskala E (2018) International consensus statement on allergy and rhinology: allergic rhinitis-executive summary. Int Forum Allergy Rhinol 8(2):85-107. https://doi.org/10. 1002/alr.22070

10. Scadding G, Hellings P, Alobid I, Bachert C, Fokkens W, van Wijk RG, Gevaert P, Guilemany J, Kalogjera L, Lund V, Mullol J, Passalacqua G, Toskala E, van Drunen C (2011) Diagnostic tools in rhinology EAACI position paper. Clin Transl Allergy 1(1):2. https://doi.org/10.1186/2045-7022-1-2

11. Hellings PW, Scadding G, Alobid I, Bachert C, Fokkens WJ, Gerth van Wijk R, Gevaerts P, Guilemany J, Kalogjera L, Lund VJ, Mullol J, Passalacqua G, Toskala E, van Drunen CM (2012)
Executive summary of European Task Force document on diagnostic tools in rhinology. Rhinology 50(4):339-352. https://doi. org/10.4193/Rhino11.252

12. Murray AB, Milner RA (1995) The accuracy of features in the clinical history for predicting atopic sensitization to airborne allergens in children. J Allergy Clin Immunol 96(5 Pt 1):588-596. https://doi.org/10.1016/s0091-6749(95)70256-3

13. Bousquet J, Khaltaev N, Cruz AA, Denburg J, Fokkens WJ, Togias A, Zuberbier T, Baena-Cagnani CE, Canonica GW, van Weel C, Agache I, Ait-Khaled N, Bachert C, Blaiss MS, Bonini S, Boulet LP, Bousquet PJ, Camargos P, Carlsen KH, Chen Y, Custovic A, Dahl R, Demoly P, Douagui H, Durham SR, van Wijk RG, Kalayci O, Kaliner MA, Kim YY, Kowalski ML, Kuna P, Le LT, Lemiere C, Li J, Lockey RF, Mavale-Manuel S, Meltzer EO, Mohammad Y, Mullol J, Naclerio R, O’Hehir RE, Ohta K, Ouedraogo S, Palkonen S, Papadopoulos N, Passalacqua G, Pawankar R, Popov TA, Rabe KF, Rosado-Pinto J, Scadding GK, Simons FE, Toskala E, Valovirta E, van Cauwenberge P, Wang DY, Wickman M, Yawn BP, Yorgancioglu A, Yusuf OM, Zar H, Annesi-Maesano I, Bateman ED, Ben KA, Boakye DA, Bouchard J, Burney P, Busse WW, Chan-Yeung M, Chavannes NH, Chuchalin A, Dolen WK, Emuzyte R, Grouse L, Humbert M, Jackson C, Johnston SL, Keith PK, Kemp JP, Klossek JM, Larenas-Linnemann D, Lipworth B, Malo JL, Marshall GD, Naspitz C, Nekam K, Niggemann B, Nizankowska-Mogilnicka E, Okamoto Y, Orru MP, Potter P, Price D, Stoloff SW, Vandenplas O, Viegi G, Williams D, World Health O., Galen and AllerGen (2008) Allergic rhinitis and its impact on asthma (ARIA) 2008 update (in collaboration with the World Health Organization, GA(2)LEN and AllerGen). Allergy 63(Suppl 86):8-160. https://doi.org/10.1111/j.1398-9995.2007.01620.x

14. Pfaar O, Bachert C, Bufe A, Buhl R, Ebner C, Eng P, Friedrichs F, Fuchs T, Hamelmann E, Hartwig-Bade D, Hering T, Huttegger I, Jung K, Klimek L, Kopp MV, Merk H, Rabe U, Saloga J, Schmid-Grendelmeier P, Schuster A, Schwerk N, Sitter H, Umpfenbach U, Wedi B, Wohrl S, Worm M, Kleine-Tebbe J, Kaul S, Schwalfenberg A (2014) Guideline on allergen-specific immunotherapy in IgE-mediated allergic diseases: S2k Guideline of the German Society for Allergology and Clinical Immunology (DGAKI), the Society for Pediatric Allergy and Environmental Medicine (GPA), the Medical Association of German Allergologists (AeDA), the Austrian Society for Allergy and Immunology (OGAI), the Swiss Society for Allergy and Immunology (SGAI), the German Society of Dermatology (DDG), the German Society of Oto- Rhino-Laryngology, Head and Neck Surgery (DGHNOKHC), the German Society of Pediatrics and Adolescent Medicine (DGKJ), the Society for Pediatric Pneumology (GPP), the German Respiratory Society (DGP), the German Association of ENT Surgeons (BV-HNO), the Professional Federation of Paediatricians and Youth Doctors (BVKJ), the Federal Association of Pulmonologists (BDP) and the German Dermatologists Association (BVDD). Allergo J Int 23(8):282-319. https://doi.org/10. 1007/s40629-014-0032-2

15. Gosepath J, Amedee RG, Mann WJ (2005) Nasal provocation testing as an international standard for evaluation of allergic and nonallergic rhinitis. Laryngoscope 115(3):512-516. https://doi. org/10.1097/01.MLG.0000149682.56426.6B

16. Comite P, Minale P, Ferrero F, Mussap M, Ciprandi G (2015) Der p $1 \mathrm{IgE}$ measurement for distinguishing between sensitization and allergy. Immunol Lett 166(2):145-146. https://doi.org/10.1016/j. imlet.2015.06.004

17. Haxel BR, Huppertz T, Boessert P, Bast F, Fruth K (2016) Correlation of skin test results and specific immunoglobulin $\mathrm{E}$ blood levels with nasal provocation testing for house-dust mite allergies. Am J Rhinol Allergy 30(1):60-64. https://doi.org/10.2500/ajra. 2016.30.4262 
18. Kohl C, Debelic M (1991) In vitro screening for inhalant allergy with multi SX 1 RAST (Phadiatop). Allergy 46(4):245-250. https://doi.org/10.1111/j.1398-9995.1991.tb00581.x

19. Rasp G (1992) Allergic rhinopathy: Magic Lite SQ Allergy Screen Inhalant and CAP-FEIA SX1-comparison of two allergen-specific screening tests in serum. Laryngorhinootologie 71(6):298-301. https://doi.org/10.1055/s-2007-997299

20. Juniper EF, Guyatt GH (1991) Development and testing of a new measure of health status for clinical trials in rhinoconjunctivitis. Clin Exp Allergy 21(1):77-83. https://doi.org/10.1111/j.13652222.1991.tb00807.x

21. Juniper EF, Guyatt GH, Griffith LE, Ferrie PJ (1996) Interpretation of rhinoconjunctivitis quality of life questionnaire data. $\mathrm{J}$ Allergy Clin Immunol 98(4):843-845. https://doi.org/10.1016/ s0091-6749(96)70135-5

22. Bernstein IL, Storms WW (1995) Practice parameters for allergy diagnostic testing. Joint task force on practice parameters for the diagnosis and treatment of asthma. The American Academy of Allergy, Asthma and Immunology and the American College of Allergy, Asthma and Immunology. Ann Allergy Asthma Immunol 75(6 Pt 2):543-625

23. Gellrich D, Hogerle C, Becker S, Groger M (2019) Is quantitative sIgE serology suitable for distinguishing between silent sensitization and allergic rhinitis to dermatophagoides pteronyssinus? J Investig Allergol Clin Immunol 29(2):124-131. https://doi.org/ 10.18176/jiaci.0299

24. Cazan D, Hackenberg B, Pfaar O, Klimek L (2013) Die nasale Provokationstestung mit Allergenen Methoden der klinischen Anwendung. Allergo J 22(3):189-202. https://doi.org/10.1007/ s15007-013-0090-7

25. Riechelmann H, Bachert C, Goldschmidt O, Hauswald B, Klimek L, Schlenter WW, Tasman AJ, Wagenmann M (2002) Provokationstests bei Erkrankungen der oberen Atemwege. Allergo J 11:29-36

26. GINA (2020) The global strategy for asthma management and prevention

27. Klimek L (1997) Allergologie und Umweltmedizin. ISBN 3-79451756-3. Schattauer Schattauer, Stuttgart

28. Klimek L, Bachert C, Pfaar O, Becker S, Bieber T, Brehler R, Buhl R, Casper I, Chaker A, Czech W, Fischer J, Fuchs T, Gerstlauer M, Hormann K, Jakob T, Jung K, Kopp MV, Mahler V, Merk H, Mulleneisen N, Nemat K, Rabe U, Ring J, Saloga J, Schlenter W, Schmidt-Weber C, Seyfarth H, Sperl A, Spindler T, Staubach P, Strieth S, Treudler R, Vogelberg C, Wallrafen A, Wehrmann W, Wrede H, Zuberbier T, Bedbrook A, Canonica GW, Cardona V, Casale TB, Czarlewski W, Fokkens WJ, Hamelmann E, Jutel M, Larenas-Linnemann D, Mullol J, Papadopoulos NG, Toppila-Salmi S, Werfel T, Bousquet J (2019) ARIA guideline 2019: treatment of allergic rhinitis in the German health system. Allergol Select 3(1):22-50. https://doi.org/10.5414/ALX02120E

29. Bousquet PJ, Castelli C, Daures JP, Heinrich J, Hooper R, Sunyer J, Wjst M, Jarvis D, Burney P (2010) Assessment of allergen sensitization in a general population-based survey (European Community Respiratory Health Survey I). Ann Epidemiol 20(11):797803. https://doi.org/10.1016/j.annepidem.2010.05.012

30. Arbes SJ, Jr., Gergen P. J., Elliott L. and Zeldin D. C. (2005) Prevalences of positive skin test responses to 10 common allergens in the US population: results from the third National Health and Nutrition Examination Survey. J Allergy Clin Immunol 116(2):377-383. https://doi.org/10.1016/j.jaci.2005.05.017

31. Skoner DP (2001) Allergic rhinitis: definition, epidemiology, pathophysiology, detection, and diagnosis. J Allergy Clin Immunol 108(1 Suppl):S2-8. https://doi.org/10.1067/mai.2001.115569

32. Brozek JL, Bousquet J, Agache I, Agarwal A, Bachert C, BosnicAnticevich S, Brignardello-Petersen R, Canonica GW, Casale T, Chavannes NH, Correia de Sousa J, Cruz AA, Cuello-Garcia CA,
Demoly P, Dykewicz M, Etxeandia-Ikobaltzeta I, Florez ID, Fokkens W, Fonseca J, Hellings PW, Klimek L, Kowalski S, Kuna P, Laisaar KT, Larenas-Linnemann DE, Carlsen KC, Manning PJ, Meltzer E, Mullol J, Muraro A, O’Hehir R, Ohta K, Panzner P, Papadopoulos N, Park HS, Passalacqua G, Pawankar R, Price D, Riva JJ, Roldan Y, Ryan D, Sadeghirad B, Samolinski B, Schmid-Grendelmeier P, Sheikh A, Togias A, Valero A, Valiulis A, Valovirta E, Ventresca M, Wallace D, Waserman S, Wickman M, Wiercioch W, Yepes-Nunez JJ, Zhang L, Zhang Y, Zidarn M, Zuberbier T, Schunemann HJ (2017) Allergic rhinitis and its impact on asthma (ARIA) guidelines-2016 revision. J Allergy Clin Immunol 140(4):950-958. https://doi.org/10.1016/j.jaci. 2017.03.050

33. Blaiss MS, Hammerby E, Robinson S, Kennedy-Martin T, Buchs S (2018) The burden of allergic rhinitis and allergic rhinoconjunctivitis on adolescents: a literature review. Ann Allergy Asthma Immunol 121(1):43-52 e3. https://doi.org/10.1016/j. anai.2018.03.028

34. Canonica GW, Bousquet J, Mullol J, Scadding GK, Virchow JC (2007) A survey of the burden of allergic rhinitis in Europe. Allergy 62(Suppl 85):17-25. https://doi.org/10.1111/j.13989995.2007.01549.x

35. Klossek JM, Annesi-Maesano I, Pribil C, Didier A (2012) The burden associated with ocular symptoms in allergic rhinitis. Int Arch Allergy Immunol 158(4):411-417. https://doi.org/10. $1159 / 000334286$

36. Neto HJ, Rosario NA, Westphal GL, Riedi CA, Santos HL (2010) Allergic conjunctivitis in asthmatic children: as common as underreported. Ann Allergy Asthma Immunol 105(5):399_ 400. https://doi.org/10.1016/j.anai.2010.08.020

37. Steppuhn H, Kuhnert R, Scheidt-Nave C (2017) 12-MonatsPrävalenz von Asthma bronchiale bei Erwachsenen in Deutschland. Robert Koch-Institut, Epidemiologie und Gesundheitsberichterstattung. J Health Monitor

38. Miller JD (2019) The role of dust mites in allergy. Clin Rev Allergy Immunol 57(3):312-329. https://doi.org/10.1007/ s12016-018-8693-0

39. Schneider L, Tilles S, Lio P, Boguniewicz M, Beck L, LeBovidge J, Novak N, Bernstein D, Blessing-Moore J, Khan D, Lang D, Nicklas R, Oppenheimer J, Portnoy J, Randolph C, Schuller D, Spector S, Tilles S, Wallace D (2013) Atopic dermatitis: a practice parameter update 2012. J Allergy Clin Immunol 131(2):295-299 e1-27. https://doi.org/10.1016/j.jaci.2012.12. 672

40. Peat JK, Tovey E, Toelle BG, Haby MM, Gray EJ, Mahmic A, Woolcock AJ (1996) House dust mite allergens. A major risk factor for childhood asthma in Australia. Am J Respir Crit Care Med 153(1):141-146. https://doi.org/10.1164/ajrccm.153.1.8542107

41. Celedon JC, Milton DK, Ramsey CD, Litonjua AA, Ryan L, Platts-Mills TA, Gold DR (2007) Exposure to dust mite allergen and endotoxin in early life and asthma and atopy in childhood. J Allergy Clin Immunol 120(1):144-149. https://doi.org/10.1016/j. jaci.2007.03.037

42. Zureik M, Neukirch C, Leynaert B, Liard R, Bousquet J, Neukirch F, European Community Respiratory Health S. (2002) Sensitisation to airborne moulds and severity of asthma: cross sectional study from European Community respiratory health survey. BMJ 325(7361):411-414. https://doi.org/10.1136/bmj.325.7361.411

43. Darsow U, Laifaoui J, Kerschenlohr K, Wollenberg A, Przybilla B, Wuthrich B, Borelli S Jr, Giusti F, Seidenari S, Drzimalla K, Simon D, Disch R, Borelli S, Devillers AC, Oranje AP, De Raeve L, Hachem JP, Dangoisse C, Blondeel A, Song M, Breuer K, Wulf A, Werfel T, Roul S, Taieb A, Bolhaar S, Bruijnzeel-Koomen C, Bronnimann M, Braathen LR, Didierlaurent A, Andre C, Ring J (2004) The prevalence of positive reactions in the atopy patch test with aeroallergens and food allergens in subjects with atopic 
eczema: a European multicenter study. Allergy 59(12):13181325. https://doi.org/10.1111/j.1398-9995.2004.00556.x

44. Tupker RA, De Monchy JG, Coenraads PJ, Homan A, van der Meer JB (1996) Induction of atopic dermatitis by inhalation of house dust mite. J Allergy Clin Immunol 97(5):1064-1070. https://doi.org/10.1016/s0091-6749(96)70259-2

45. Liu J, Zhang X, Zhao Y, Wang Y (2020) The association between allergic rhinitis and sleep: a systematic review and meta-analysis of observational studies. PLoS ONE 15(2):e0228533. https://doi. org/10.1371/journal.pone.0228533

46. Young T, Finn L, Kim H (1997) Nasal obstruction as a risk factor for sleep-disordered breathing. The University of Wisconsin Sleep and Respiratory Research Group. J Allergy Clin Immunol 99(2):S757-S762. https://doi.org/10.1016/s0091-6749(97) 70124-6

47. Young T, Finn L, Palta M (2001) Chronic nasal congestion at night is a risk factor for snoring in a population-based cohort study. Arch Intern Med 161(12):1514-1519. https://doi.org/10. 1001/archinte.161.12.1514

48. Thompson A, Sardana N, Craig TJ (2013) Sleep impairment and daytime sleepiness in patients with allergic rhinitis: the role of congestion and inflammation. Ann Allergy Asthma Immunol 111(6):446-451. https://doi.org/10.1016/j.anai.2013.05.020

49. Hughes K, Glass C, Ripchinski M, Gurevich F, Weaver TE, Lehman E, Fisher LH, Craig TJ (2003) Efficacy of the topical nasal steroid budesonide on improving sleep and daytime somnolence in patients with perennial allergic rhinitis. Allergy 58(5):380-385. https://doi.org/10.1034/j.1398-9995.2003.00093.x

50. Gurevich F, Glass C, Davies M, Wei W, McCann J, Fisher L, Chegini S, Mende C, Craig T (2005) The effect of intranasal steroid budesonide on the congestion-related sleep disturbance and daytime somnolence in patients with perennial allergic rhinitis. Allergy Asthma Proc 26(4):268-274

51. Biddulph P, Colloff MJ (2010) Dust mites. Exp Appl Acarol 52(4):449-450. https://doi.org/10.1007/s10493-010-9407-3

52. Simpson A, Simpson B, Custovic A, Cain G, Craven M, Woodcock A (2002) Household characteristics and mite allergen levels in Manchester, UK. Clin Exp Allergy 32(10):1413-1419. https:// doi.org/10.1046/j.1365-2745.2002.01496.x

53. Gehring U, de Jongste JC, Kerkhof M, Oldewening M, Postma D, van Strien RT, Wijga AH, Willers SM, Wolse A, Gerritsen J, Smit HA, Brunekreef B (2012) The 8-year follow-up of the PIAMA intervention study assessing the effect of mite-impermeable mattress covers. Allergy 67(2):248-256. https://doi.org/10.1111/j. 1398-9995.2011.02739.x

Publisher's Note Springer Nature remains neutral with regard to jurisdictional claims in published maps and institutional affiliations. 